\title{
Counselor Candidates' Journey to Self-Awareness: Personality Theories
}

\section{Psikolojik Danışman Adaylarının Kendini Tanıma Yolculuğu: Kişilik Kuramları}

\author{
Zeynep şi̇MŞİR*
}

Received: 16 January 2021

Research Article

Accepted: 27 April 2021

ABSTRACT: Self-awareness is one of the main characteristics of effective counselors. However, there is no course to help increase the level of self-awareness of counselor candidates in the Guidance and Psychological Counseling (GPC) curriculum in Turkey. The present study aimed to discover the opinions of counselor candidates about the course of personality theories in the GPC undergraduate program in the 4th semester on the contribution of their selfawareness. The phenomenology design was used in this qualitative study. Forty-five counselor candidates who took the course of personality theories during one semester (14 weeks) participated in the study. A semi-structured interview form consisting of open-ended questions was used to collect the data. As a result of analyzing data with descriptive and content analysis, the themes of the awareness of personality traits, awareness of personality development, self-discovery, situational awareness, predisposition to being a counselor, and categories under these themes emerged. These results revealed that the course of personality theories contributes to the counselor candidates to know themselves better and increase their level of self-awareness. The findings were discussed in light of the relevant literature, and recommendations were provided for counselor educators.

Keywords: Self-awareness, effective counselor characteristics, counselor candidates, personality theories, phenomenology.

ÖZ: Öz-farkındalık, etki yaratan psikolojik danışmanların temel özelliklerinden biridir. Ancak Türkiye'deki Rehberlik ve Psikolojik Danışmanlık (RPD) müfredatında psikolojik danışman adaylarının öz-farkındalık düzeyini artırmaya yönelik doğrudan bir ders bulunmamaktadır. Bu araştırmanın amacı, RPD lisans programında 4. yarıyılda bulunan kişilik kuramları dersinin psikolojik danışman adaylarının öz-farkındalıklarına katkısına ilişkin görüşlerini incelemektir. Nitel yöntemle gerçekleştirilen bu araştırmada fenomenoloji deseni kullanılmıştır. Araştırmaya bir dönem boyunca (14 hafta) kişilik kuramları dersini alan 45 psikolojik danışman adayı katılmıştır. Verilerin toplanmasında açık uçlu sorulardan oluşan yarı yapılandırılmış görüşme formu kullanılmıştır. Elde edilen veriler betimsel ve içerik analizi yöntemi ile analiz edilmiştir. Analiz neticesinde kişilik özelliklerine ilişkin farkındalık, kişilik gelişimine ilişkin farkındalık, kendini keşfetme, durumsal farkındalık, psikolojik danışmanlığa yatkınlık temaları ve bu temalar altında kategoriler ortaya çıkmıştır. Bu sonuçlar kişilik kuramları dersinin psikolojik danışman adaylarının kendilerini daha iyi tanımlarına ve öz-farkındalık düzeylerinin artmasına katkı sağladığına işaret etmektedir. Araştırma sonuçları ilgili literatür ışığında tartışılmış ve psikolojik danışman eğitimcileri için öneriler sunulmuştur.

Anahtar kelimeler: Öz-farkındalık, etkili psikolojik danışman nitelikleri, psikolojik danışman adayları, kişilik kuramları, fenomenoloji.

* Dr., Selcuk University, Konya, Turkey, zey.simsir.93@gmail.com, https://orcid.org/0000-0003-2353-8922

Citation Information

Şimşir, Z. (2021). Counselor candidates' journey to self-awareness: Personality theories. Kuramsal Eğitimbilim Dergisi [Journal of Theoretical Educational Science], 14(3), 308-322. 
Counseling profession encompassing a broad variety of application areas today (e.g., school, industry, sports) and expanding in recent years with a rich and long history. Throughout this history, various schools of thought have emerged, different realms of help have been established, and the profession has progressively adopted a descriptive set of values (Hansen, 2009). Along with this set of values, professional requirements identified essential competencies a counselor must have (Corey, 2008; Cormier \& Cormier, 1991; Yalçın, 2006). The main competence areas that counselors required can be listed as having personal characteristics, counseling skills, and professional knowledge (Yalçın, 2006). According to Cormier and Cormier (1991), an effective counselor's skills are intellectual competence, energy, flexibility, support, goodwill, and self-awareness. Hackney and Cormier (2008), on the other hand, describe the characteristics of effective counselors; having personal awareness and understanding, being psychologically healthy, sensitivity and understanding of the effects of ethnic origin and cultural factors on oneself and others, being open-minded, being objective, competent, being reliable and attractive in interpersonal relationships.

Self-awareness, which is one of the personal characteristics that psychological counselors should possess, has been regarded as a critical element for effective therapy and counseling (Fauth \& Williams, 2005; Hackney \& Cormier, 2008; Hansen, 2009; Hernández et al., 2010; Pieterse et al., 2013). Theorists who believe that a counselor should know him/herself before knowing others and the current literature emphasize the significance of a therapist's self-awareness that is fundamental to know oneself is to know others (DiVirgilio, 2018). Moreover, the Council for Accreditation of Counseling and Related Educational Programs (CACREP, 2016) accepted the significance of selfawareness. It went a step further by stating that the existence of self-awareness is an essential criterion for a counselor qualification. Self-awareness is distinctly important because the high level of self-awareness in the counselors makes them feel free, safe, focused, harmonious, and competent when working with their clients (Vallance, 2004). Besides, counselors with low self-awareness are more likely to fail to continue the counseling process. An effective counselor should know their limitations, strengths, needs, expectations, and goals (Cormier \& Cormier, 1991). Schneider-Corey and Corey (2002) also argued that a therapist with low awareness cannot help clients to gain selfawareness. It is obvious that the concept of self-awareness is enormously appreciated by the counseling profession.

Although the counseling profession has given high importance to the selfawareness of practitioners, the use of the term is problematic. There are diverse definitions of self-awareness in literature, indicating that each researcher can be referencing a different concept when they use "self-awareness" (Nutt-Williams, 2008; Uhlemann \& Jordan, 1981; Williams, 2003). Most of the researchers have defined selfawareness as a global sense of self-knowledge (A capability to have understanding into one's personality and the internal world), but self-awareness has also been described as a temporary state of awareness, just as self-consciousness, and self-focused attention (e.g., Fauth \& Williams, 2005; Nutt-Williams, 2008). Temporary self-awareness situations can be micro-states that are a part of the macro-structure of self-awareness (Pieterse et al., 2013). In addition, the conceptualization of general self-awareness has often been referred as a critical and positive part of therapy (Hernández et al., 2010; 
Pieterse et al., 2013). Thus, in the present study, the counselor's self-awareness was handled as a general self-awareness.

General self-awareness refers to a state of being aware of one's feelings, beliefs, thoughts, actions, and attitudes, and knowing how these issues are shaped by significant aspects of one's developmental and communal history (Cormier \& Cormier, 1991; Pieterse et al., 2013; Pompeo \& Levitt, 2014). Jevne's (1981) survey showed six components of self-awareness: values and attitudes, emotional responses, proficiencies, needs/desires/objectives, personal restrictions, and personal impression (as cited in Uhlemann \& Jordan, 1981). Likewise, Schneider-Corey and Corey (2002) stated that the basic characteristics of a self-aware therapeutic person are to be aware of their identity, goals, motivation, needs, strengths and weaknesses, values, cultural dynamics, emotions, and problems. In summary, the literature on counselor self-awareness has proposed that the key components in conducting effective psychotherapy are awareness of family dynamics, unresolved conflicts, cultural prejudices, and worldview (Pieterse et al., 2013).

Self-awareness and personal characteristics are essential elements of counselor education programs (Corey, 2008; Hernández et al., 2010; Pieterse et al., 2013; Uhlemann \& Jordan, 1981). The literature emphasizes that a counselor's self-awareness emerges where supervision, family therapy, and multiculturalism exist as content (Pieterse et al., 2013). Also, since the psychoanalytic theory accepted self-awareness as a basic requirement in psychotherapy, therapist training includes self-awareness practices. A group of approaches also highlight that counselors should receive personal therapy to develop self-awareness (McEwan \& Duncan, 1993). Other alternative methods for self-awareness in counselor training are personal development groups and self-awareness counseling groups (Topuz \& Arasan, 2014). However, there are major limitations in the counseling literature about models and researches for self-awareness training (e.g., Pieterse et al., 2013; Pompeo \& Levitt, 2014). Moreover, counseling programs neglect the importance of personal development and self-awareness while focusing more on skills such as evaluation, intervention strategies, psychopathology, and treatment in counselor education (Hernández et al., 2010; Myers, 2003).

\section{The Present Study}

As in the counseling programs around the world, there is no course in the curriculum that aims to increase the personal awareness and development of the counselor students in the Guidance and Psychological Counseling (GPC) undergraduate program in Turkey. However, the content of the course of personality theories in the 4th semester of the 4-year undergraduate program includes the basic concepts of personality, development of personality, harmony and mental health; learning the characteristics of personality theories and associating them with field practices (The Council of Higher Education, 2018). Within the scope of the course, many theories from psychoanalytic theories of personality to behavioral theories, from humanistic/existential theory to cognitive theories are introduced. Theorists' views on human, personality and personality development are presented (Burger, 2006; Cervone \& Pervin, 2016; Yazgan-İnanç \& Yerlikaya, 2016). In this respect, this course opens a new window for students to know themselves, make inferences about their personalities and personal development. Therefore, the views of counselor candidates on the course 
of personality theories on the contribution of their self-awareness were examined in this study. In the light of these explanations, the objectives of the study are as follows:

Based on the course of personality theories;

1. How do counselor candidates define their personality traits?

2. How is the counselor candidates' awareness about the development of their personalities?

3. What traits did the counselors discover themselves?

4. What kind of gains have the counselor candidates obtained in terms of pastpresent-future awareness?

5. How can counselor candidates gain awareness of whether their characteristics are prone to be counseling or not?

\section{Method}

\section{Research Design}

In this study, the phenomenology design, one of the qualitative research designs, was utilized to determine the change in the self-awareness of the counselor candidates after taking the course of personality theories. The phenomenology design tries to reach the essence of the experience by asking questions about the experiences related to the phenomenon (Creswell, 2013; Patton, 2014; Saban \& Ersoy, 2016).

\section{Participants}

Forty-five counselor candidates (30 female, 15 male) studying at the Department of GPC at a state university in Konya participated in the study. Participants have completed the second class (4th semester) and studied in the same class. Participants were chosen according to the criterion sampling method, one of the purposeful sampling methods, in line with the purpose of the study. The purposeful sampling method is a widely used sampling method that is suitable for the qualitative research tradition (Patton, 2014; Yıldırım \& Şimşek, 2013). Criterion sampling, which is one of the purposeful sampling types, is the inclusion of individuals who meet a predetermined set of criteria (Yıldırım \& Şimşek, 2013). The criterion was set for the participants in this study are to attend the course of personality theories one semester and pass this course successfully.

\section{Data Collection Tools and Process}

To examine the opinions of the counselor candidates on self-awareness in depth at the end of the course of personality theories, a semi-structured interview form consisting of open-ended questions was used (Yıldırım \& Şimşek, 2013). The data collection tool was created in light of the relevant literature and in line with the subproblems of the research. To measure the appropriateness of the questions, the opinions of three experts who have experience in qualitative research in the field were taken into consideration. The questions were revised based on the feedback and suggestions of the experts. Then, the opinions of three counselor candidates were taken to determine whether the questions were understandable or not, and the questionnaire form was finalized by considering the students' opinions. During the data collection, the participants were informed about the purpose of the study and how to answer the 
questions. It was also stated that answering the questions is based on voluntariness, that they can answer questions freely, and they are assured that their answers will remain confidential.

\section{Data Analysis}

Content analysis and descriptive analysis methods were used together for the data analysis. The main purpose of content analysis is to obtain concepts and relationships to explain the data. During the content analysis, unpredictable themes and categories have emerged after the data is analyzed in depth. The descriptive analysis method is used in studies of which conceptual structure or themes are predetermined. Therefore, the collected data is summarized and interpreted according to predetermined themes (Yıldırım \& Şimşek, 2013).

The data were analyzed in line with the suggestions of Miles and Huberman (2019) and the following steps were followed respectively: (a) data collection, (b) data reduction, (c) data representation, and (d) deduction, and verification.

In the first step of data analysis, the written responses of the students to openended questions were compiled and numbered. In the data reduction step, the data were organized, sorted and an analytical selection was made. At this step, the data were processed one by one and coded. Coding is the essence of the analysis of qualitative data analysis. During the coding process, the data were reviewed, synthesized, and meaningful categories and themes were created by preserving the integrity of the relations between the texts. Coding was carried out with a flexible approach with the repetitive cycle of induction and deduction. Then, the validity and reliability of the results were examined, and the results were confirmed. Finally, the results had been visualized with tables for the readers to enable them to grasp it better (Miles \& Huberman, 2019). Data were analyzed using NVivo 11 software. This program has facilitated the coding of data and the creation of themes and categories.

\section{Establishment of Trustworthiness}

The following measures have been taken to increase the validity and reliability of the analysis results (Miles \& Huberman, 2019; Yıldırım \& Şimşek, 2013):

To increase the credibility (internal validity), expert opinion was involved in each step of the study, from the preparation of the interview questions to the analysis phase. To obtain an in-depth understanding, besides a questionnaire form consisting of semi-structured questions, and open-ended questions were asked. To increase the transferability (external validity) of the results, each step of the qualitative study was explained in detail. The themes and categories were presented visually so that the reader can easily understand, and the findings were supported with direct quotations. However, while making direct quotations, coding with gender $(\mathrm{M} / \mathrm{F}$ ) and number (such as $\mathrm{M}$, M2, F3 .. F45) is used instead of the names of the participants due to the confidentiality principle. In order to increase the consistency (internal reliability), themes and categories were examined by three researchers with qualitative research experience, and minor changes were made based on the researchers' suggestions. To provide confirmation (external reliability), the data were coded on different dates, and the coefficient of agreement between the emerging themes and categories was examined. The coefficient of the agreement was calculated as $90 \%$. 


\section{Results}

In this section, the themes and categories that emerged after analyzing the opinions of the counselor candidates, and quotations from the participants' opinions are included. In the analysis, five themes and categories emerged: awareness of personality traits, awareness of personality development, self-discovery, situational awareness, and predisposition to being a counselor.

\section{Awareness of Personality Traits}

Counselor candidates who took the course of personality theories during the semester were asked to describe and explain their personality based on this course. As seen in Table 1, counselor candidates took personality theories as a reference while defining their personalities and described themselves based on this information. Looking at the answers given by the counselor candidates, the most commonly expressed personality trait is extroversion, and the personality traits of introversion, agreeableness, conscientiousness, openness to experience, and neuroticism follow this answer respectively.

Table 1

The Categories and Sample Statements of the Awareness of Personality Traits Theme

\begin{tabular}{|c|c|}
\hline Categories & Sample statements \\
\hline $\begin{array}{l}\text { Extroversion } \\
(\mathrm{f}=13)\end{array}$ & $\begin{array}{l}\text { "Extroversion, which is the basic concept of analytical psychology, defines me } \\
\text { accurately. Where the social activity is, I am there. You can understand this from } \\
\text { the SAKA student club that I established with my friends and the projects I have } \\
\text { done in this club. I have a friendly personality who likes to touch onto lives and } \\
\text { spend time with people." (F16) }\end{array}$ \\
\hline $\begin{array}{l}\text { Introversion } \\
(\mathrm{f}=11)\end{array}$ & $\begin{array}{l}\text { "I define my personality as an introvert. I am not good at building close } \\
\text { relationships with people, trusting, giving them confidence. I don't like crowded } \\
\text { places. I love being alone and mindful. (M10) }\end{array}$ \\
\hline $\begin{array}{l}\text { Agreeableness } \\
(\mathrm{f}=8)\end{array}$ & $\begin{array}{l}\text { "I am a mild-tempered and caring person. I overthink and struggle especially in } \\
\text { details." (F13) }\end{array}$ \\
\hline $\begin{array}{l}\text { Conscientiousness } \\
(\mathrm{f}=6)\end{array}$ & $\begin{array}{l}\text { "I am a rather responsible and success-oriented person, sensitive and somewhat } \\
\text { obsessed. It is difficult for me to get used to the new things, to absorb them in my } \\
\text { life." (F14) }\end{array}$ \\
\hline $\begin{array}{l}\text { Openness to } \\
\text { experience } \\
(\mathrm{f}=6)\end{array}$ & $\begin{array}{l}\text { "I like different hobbies and trying different things. But the concept of birth order } \\
\text { in Alfred Adler's theory, which I had the opportunity to examine with this lesson, } \\
\text { helped me a bit in this regard. Because I'm also the fifth and last child at home. I } \\
\text { have never been a shy person since childhood. It can also be said that I am an } \\
\text { outgoing person. I attach great importance to innovative ideas instead of steady } \\
\text { ones." (F22) }\end{array}$ \\
\hline $\begin{array}{l}\text { Neuroticism } \\
(\mathrm{f}=5)\end{array}$ & $\begin{array}{l}\text { "I generally follow my emotions; I am not a person who decides with his/her } \\
\text { logic. I am usually an anxious and stressed person. I constantly think about the } \\
\text { past and feel regretful. I think about the future and feel worried. My most } \\
\text { distinctive feature may be that I get angry very quickly. Things that would never } \\
\text { affect a normal person can make me very angry." (M3) }\end{array}$ \\
\hline
\end{tabular}




\section{Awareness of Personality Development}

In order to examine the awareness of counselor candidates about their personality development, we asked "Which factors do you think have the most influence on your personality development? Please explain briefly." Counselor candidates argued that personality development is influenced by family dynamics, environment, early experiences, attachment style, and genetic (Table 2). As can be seen in the table, most of the counselor candidates emphasized family dynamics. Participants stated that the family is the environment where they were born and raised and that their parents' child-rearing attitude shaped their personalities. Another factor that counselor candidates emphasize most in personality development is the environment. However, the influence of genetic factors and attachment styles has been neglected by most of the counselor candidates and these factors are not frequently mentioned.

Table 2

The Categories and Sample Statements of Awareness of Personality Development Theme

\begin{tabular}{ll}
\hline \multicolumn{1}{c}{ Categories } & \multicolumn{1}{c}{ Sample statements } \\
\hline Family dynamics & "My family has been the most influential factor of my life in terms of my \\
personality growth. I think, it naturally happens that the family gets involve in \\
shaping a personality of a child as a role model. For example, in my case, I \\
would say why I am not very self-confident about myself is that my family. \\
Because, I am profoundly affected in negative ways by their attitude towards \\
me as they did not give me a space or let me to talk on behalf of myself when I \\
am young. They even used to fulfill duties which I was the one who was \\
supposed to do." (M31) \\
"I believe that the environment I live in affects both my thoughts and my \\
personality. Because the environment I live in has transferred the cultural and \\
other values to me as I was growing. Therefore, I believe that the environment \\
has affected and improved me the most in my personality development. The \\
influence of the environment is bigger because personality develops around \\
certain value judgments and moral rules. The environment I am in has shaped \\
my view of the world. I think someone's perspective is a concept which \\
directly related to personality. That's why the environment affects my \\
personality the most. There is a motto that says, "geography is destiny". I \\
changed this motto with: "The environment we live in is our personality, and it \\
is our preferences that shape our destiny." (F19)
\end{tabular}

Early experiences $(\mathrm{f}=16)$

Attachment style $(\mathrm{f}=3)$
"When I think of my childhood experiences, some negative events which shaped the development of my personality have happened to me, and I can say that these experiences affected me greatly. To be honest, the traces of my childhood continue to affect my behavior and thoughts that is me." (M4)

"My attachment style is also somewhat effective in my personality development. My family's attitude towards me since I was little has been inconsistent. Therefore, I have a fearful-anxious attachment style. Right now, I can't be sure if people love me. I don't trust anyone. I generally consider myself worthless in relationships. I always think of ideas like 'You deserve this, 'You are not worthy to be loved anyway '...” (F35)

Genetic

“...The genes brought us into the world also affect our personality." (F16) 


\section{Self-Discovery}

The answers given by the counselor candidates were combined under four categories to the question of how theories they learned during the course of personality theories contribute to self-discovery: Strengths and weaknesses; habits; feelings, thoughts, and behaviors; values, beliefs, and culture (Table 3). Most of the counselor candidates stated that their awareness of their feelings, thoughts, and behaviors increased at the end of this course. Likewise, most of the participants noted that personality theories guide them in recognizing their strengths and weaknesses. Also, many counselor candidates have become more aware of their habits and emphasized their increased awareness of the influence of values, beliefs, and culture on their behavior.

Table 3

The Categories and Sample Statements of the Self-Discovery Theme Categories

Sample statements

Feelings, thoughts, "One of the most important things this lesson taught me is that personality and behaviors $(\mathrm{f}=31)$ manifests itself in emotions, thoughts, and behaviors. So, thanks to this lesson, I learned the underlying reasons for my feelings and thoughts. Horney's thoughts on women and his idea of equality between men and women further supported my thoughts on this issue. Erik Fromm's view of freedom helped me realize my views on this subject. In this context, the course of personality theories helped me to understand my feelings and thoughts better and to develop myself in this direction." (F19)

Strengths and “At first, I was thinking 'how can we apply these theories to our lives?' But weaknesses then I realized that there was a reason for my behavior, thoughts, and actions. (f=26) For example, after studying Adler's statements, I realized that I had weaknesses. Concepts such as birth order, inferiority complex, and striving for superiority enabled me to discover my weaknesses. But likewise, for Freud's theories, I realized that I am a powerful creature and have strong feelings. Especially there is no limit to what the id can do." (M5)

Habits "I started to realize my habits that I had never thought about before. For $(\mathrm{f}=21) \quad$ example, I noticed that some of my habits are due to deficiencies. I experienced it during the oral period. I realized that my smoking habit was due to a deficiency arising from this period. I noticed that the environment has an impact on habits." (M44)

Values, beliefs, and "I realized that our values, beliefs, and culture create have led to some changes culture in our personality and life after this lesson. But most importantly, I realized

$(\mathrm{f}=18)$ that people's problems, thoughts, values, and beliefs always intersect and are similar, even from different societies and cultures. For example, everyone, regardless of religion, has an existential thought, belief, and tendency to live purposefully." (F1)

\section{Situational Awareness}

The answers are given by the counselor candidates were combined under three categories to the question of how the course of personality theories contributed to them in terms of awareness of the past, future, and present: Past, present, and future (Table 4). Most of the counselor candidates stated that they questioned how their past experiences, choices, and experiences affect their current lives and increased their level of awareness. 
They also said that their awareness of how current actions interact and shapes future actions and feeling to live in the moment has increased. Adding to that, they expressed that the past, present, and future are tightly intertwined.

Table 4

The Categories and Sample Statements of Situational Awareness Theme

\begin{tabular}{ll}
\hline \multicolumn{1}{c}{ Categories } & Sample statements \\
\hline Past & "The course of personality theories proved to me that some of my past \\
experiences, especially my childhood events, continue to have an impact on my \\
life even now. So much so that some experiences will show their effect even in \\
the future. Because childhood is both a critical period and a period when \\
attention is directed towards the environment." (F24)
\end{tabular}

\section{Predisposition to Being a Counselor}

The answers given by the counselor candidates to the question asked to examine the views of the counselor candidates on the predisposition of their personality traits to the counseling profession were collected under the trait categories suitable for psychological counseling and traits not suitable for psychological counseling (Table 5). Due to the course of personality theories, most of the students whose awareness about them increased stated that their characteristics are suitable for the counseling profession. However, they stated that some of their characteristics were not suitable for psychological counseling and they made efforts to make them right or improve these features.

Table 5

The Categories and Sample Statements of Predisposition to Being Counselor Theme

\begin{tabular}{ll}
\hline \multicolumn{1}{c}{ Categories } & \multicolumn{1}{c}{ Sample statements } \\
\hline $\begin{array}{l}\text { Traits suitable for } \\
\text { counseling }\end{array}$ & $\begin{array}{l}\text { "Trying to know and understand people has always been something I love. I } \\
\text { think I am good at interpersonal relationships. I love listening to people, trying to } \\
\text { (f=42) }\end{array}$ \\
$\begin{array}{l}\text { understand them. I respect and tolerate everyone's opinions. I am calm and a } \\
\text { person of few words, but I use them accurately. I know that counselors help the } \\
\text { client to find the right path himself, not giving advice. I believe I will do these } \\
\text { things and I think my personality identified with the counseling." (F23) }\end{array}$ \\
$\begin{array}{l}\text { Traits not suitable } \\
\text { for counseling } \\
\text { (f=24) }\end{array}$ \\
$\begin{array}{l}\text { "I think the most troublesome feature that I need to change in my personality and } \\
\text { the criticisms towards myself. I think this is a situation that I need to fix before I } \\
\text { start my career so that I build communication with people more healthy way." } \\
\text { (F42) }\end{array}$
\end{tabular}




\section{Discussion and Conclusion}

In this study, the acquirements of the self-awareness of the counselor candidates after taking the course of personality theories for one semester (14 weeks) were revealed. As a result of the analysis of the qualitative data, five themes (awareness of personality traits, awareness of personality development, self-discovery, situational awareness, predisposition to being a counselor), and various categories under these themes emerged. Counselor self-awareness and personality traits are some of the most significant elements of undergraduate and graduate counselor training programs (Hernández et al., 2010; Myers, 2003; Topuz \& Arasan, 2014; Uhlemann \& Jordan, 1981). Besides, it is considered necessary to increase the personal development of counselors who receive counseling training (Smaby et al., 2005). Although no course directly supports the self-awareness and personal development of counselor candidates in the GPD curriculum in Turkey, it can be said that the course of personality theories helps to achieve this aim, based on the study results. Similarly, Chin-Yen (1998) emphasized that psychological counseling theories and skills contribute to selfknowledge and self-understanding.

Counselor candidates began to understand personality traits better and used the classifications of the theorists after they learned in personality theories (extroversion, introversion, agreeableness, conscientiousness, openness to experience, neuroticism) while defining their personalities after taking the course of personality theories. Also counselor candidates stated that they were better aware of the factors that affect the development of their personalities, and they stated that these factors are: family dynamics, genetic, early experiences, environment, and attachment style. Other applications that increase the self-awareness of counselor candidates in the literature are participating in personal therapy (Myers, 2003) or group therapy (Topuz \& Arasan, 2014), counselor self-care (Pope \& Kline, 1999), supervisory relationship (Pieterse et al., 2013; Vallance, 2004) and self-reflective practices (DiVirgilio, 2018; Pope \& Kline, 1999). DiVirgilio (2018) revealed in his study that self-reflective practices of clinical supervision and self-reflective journal writing during graduate years increase selfawareness. Similarly, Vallance (2004) found in her qualitative research that supervision experience increased students' self-awareness.

After taking the course of personality theories, another achievement that the counselor candidates have obtained is to realize their strengths and weaknesses, habits, emotions, thoughts and behaviors, values, beliefs, and how the culture they live in affects them. Myers (2003), who conducted a similar qualitative study, did activities to increase self-awareness and gave assignments to 16 graduate students in the counseling program. Students are encouraged to get to know themselves and realize their personal development throughout this process. At the end of the program, the stories of the students on personal development were received. In these stories, the participants emphasized that they gained awareness of their personalities, realized their potential, developed more empathy with themselves and others, and improved interpersonal relationships. In another study, Jevne (1981) revealed that counselors who have a high level of self-awareness are conscious of values and attitudes, competencies, needs/wants/aspirations, personal impact, emotional reactions, and personal limits. It is rather beneficial for counselors to know the dynamics of their personality and the characteristics of the environment in which they live in order to be free from prejudice 
while establishing relationships with their clients. In this respect, the psychological counselor should be aware of its own cultural components that shape the perspective. The recommended method to develop the therapist's sensitivity to this issue is to selfexamine his/her own background from the point of race, gender, culture, social and economic class (Baker, 1999).

Counselor candidates emphasized that their situational awareness of the past, present, and future has increased after taking the course of personality theories. The role of the past in shaping the current moment and personality has been the category most frequently emphasized by counselor candidates. Global self-awareness means that, unlike momentary self-awareness, the person is also aware of himself in terms of his/her developmental history (Pompeo \& Levitt, 2014). In this context, the level of awareness of counselor candidates about how their behaviors and emotions are affected by temporal factors has increased.

The personality traits of students who receive counseling education are one of the most critical factors in terms of personal effectiveness in counseling (Carlozzi et al., 1982). The personality traits of students are a factor that facilitates the acquisition of counseling skills and the counseling training process (Pope \& Kline, 1999). In this study, counselor candidates who had the opportunity to get to know themselves better and discover their personalities by taking the course of personality theories for a semester evaluated whether their characteristics are prone to be a psychological counselor. As a result of the evaluation, most of the counselor candidates stated that they are suitable for this profession. However, they stated that some of their traits are not in line with the requirements of the profession and that they will make efforts to change these features. In a similar study, Topuz and Arasan (2014) organized counseling sessions with a self-awareness group consisting of five sessions in order to improve the level of self-awareness of counselor candidates. Counselor candidates attending the sessions had the opportunity to think about themselves further, recognize their strengths and weaknesses, and analyze what aspects of themselves are appropriate and unsuitable for being a counselor. Therefore, they gained awareness of the aspects they need to divert to be a more successful counselor.

\section{Limitations and Recommendations}

Like any other research, this study has also confronted a few limitations. Counselor candidates studying at only a state university participated in the study. Similar studies can be carried out with the participation of students studying in other universities in Turkey to eliminate this limitation. A questionnaire consisting of openended questions was used as a data collection tool in the study. It may be helpful to use additional data collection methods such as semi-structured interviews, observation, and students' personal stories to examine the participants' views further.

The suggestions for the counselor educators who teach the course of personality theories can be listed as follows: Lecturers conducting the course of personality theories can guide and support the counselor candidates knowing themselves better and personal development through assignments throughout the semester. For example, assignments can be given to the counselor candidates on which aspects of their personality they discovered based on personality theories. Counselor candidates can be encouraged to think and question by asking open-ended questions in the exams. Also, activities such as 
letter writing and drama can be carried out with students in this course. Besides, courses of counselor self-awareness can be graduate psychological counseling programs.

\section{Conclusion}

Counselor's self-awareness and personal development are some of the factors that contribute to the counseling and therapy process. For this reason, some practices are made to increase counselor self-awareness in counseling training. It is also possible to add a course of personality theories to these practices in the literature. The counselor candidates taking the course of personality theories at the undergraduate education level have a better comprehension of their personality traits and the basic dynamics that shape their personalities. Consequently, the counselor candidates began to get to know themselves better and realized how their strengths and weaknesses, habits, feelings, thoughts and behaviors, values, beliefs, and the culture they live in affect them. Counselor candidates who know themselves better have determined personality traits that are compatible and incompatible with the counseling profession have started to take some precautions.

\section{Conflicts of Interest}

There are no conflicts of interest in this study.

\section{Ethical Approval}

I declare that the research was conducted in accordance with the ethical standards of the institutional and national research committee and with the 1964 Helsinki Declaration and its later amendments or comparable ethical standards. Informed consent was obtained from all individual participants included in the study. The study was approved with the Meeting Date and Number 08.07.2020/18 by the Social and Human Sciences Ethics Committee of Bartın University. The author received no financial support for the authorship, research, and publication of this article. 


\section{References}

Baker, K. A. (1999). The importance of cultural sensitivity and therapist self-awareness when working with mandatory clients. Family Process, 38(1), 55-67. https://doi.org/10.1111/j.1545-5300.1999.00055.x

Burger, J. M. (2006). Kişilik [Personality] (İ. D. Erguvan Sarığlu, Trans.). İstanbul: Kaknüs Publications. (Original work published 1986).

Carlozzi, A. F., Campbell, N. J., \& Ward, G. R. (1982). Dogmatism and externality in locus of control as related to counselor trainee skill in facilitative responding. Counselor Education and Supervision, 21(4), 227-236.

Cervone, D., \& Pervin, L. A. (2016). Kişilik psikolojisi kuram ve araştırma [Personality psychology theory and research]. (M. Baloğlu, Trans.). Ankara: Nobel Publishing.

Chin-Yen, C. (1998). The self-awareness-training-program in counselor-education. International Conference on Counseling in the 21th century, Sydney: Australia.

Corey, G. (2008). Psikolojik danışma, psikoterapi kuram ve uygulamaları [Psychological counseling, psychotherapy theories and applications] (T. Ergene, Trans.). Ankara: Mentis Publishing. (Original work published 1977).

Cormier, W. H., \& Cormier, L. S. (1991). Interviewing strategies for helpers (3rd ed.). Pacific Grove, California: Brooks/Cole Publishing Company.

Council for Accreditation of Counseling and Related Educational Programs. (2016). Guiding principles for program evaluation and student assessment - Section 4 of the 2016 CACREP Standards. Retrieved July 10, 2020 from http://www.cacrep.org/wp-content/uploads/2017/05/Guiding-Principles-forProgram-Evaluation-and-Student-Assessment.pdf

Creswell, J. W. (2013). Qualitative research methods: Choosing among five approaches. Thousand Oaks, CA: Sage.

DiVirgilio, N. (2018). Therapist, know thyself: Self-reflective practice through autoethnography (Unpublished master dissertation). Catherine University, Minnesota, USA.

Fauth, J., \& Williams, E. N. (2005). The in-session self-awareness of therapist-trainees: Hindering or helpful? Journal of Counseling Psychology, 52(3), 443-447. https://doi.org/10..1037/0022-0167.52.3.443

Hackney, H., \& Cormier, S. (2008). Psikolojik danışma ilke ve teknikleri: Psikolojik yardım süreci el kitabı [Psychological counseling principles and techniques: Psychological help process handbook] (T. Ergene, \& S. Aydemir Sevim, Trans.). Ankara: Mentis Publishing. (Original work published 1987).

Hansen, J. T. (2009). Self-awareness revisited: Reconsidering a core value of the counseling profession. Journal of Counseling \& Development, 87(2), 186-193. https://doi.org/10.1002/j.1556-6678.2009.tb00566.x

Hernández, T. J., Seem, S. R., \& Shakoor, M. A. (2010). Counselor education admissions: A selection process that highlights candidate self-awareness and personal characteristics. The Journal of Counselor Preparation and Supervision, 2(1), 74-87. http://dx.doi.org/10.7729/21.0117 
Jevne, R. (1981). Counsellor competencies and selected issues in Canadian counsellor education. Canadian Counsellor, 15, 57-63.

McEwan, J., \& Duncan, P. (1993). Personal therapy in the training of psychologists. Canadian Psychology/Psychologie Canadienne, 34(2), 186-197.

Miles, M. B., \& Huberman, A. M. (2019). Nitel veri analizi [Qualitative meta-analysis] (S. Akbaba Altun \& A. Erson, Trans). Ankara: Pegem Academy Publishing. (Original work published 1994).

Myers, S. (2003). Reflections on reflecting: How self-awareness promotes personal growth. Person-Centered Journal, 10(1-2), 3-22.

Nutt-Williams, E. (2008). A psychotherapy researcher's perspective on therapist selfawareness and self-focused attention after a decade of research. Psychotherapy Research, 18(2), 139-146.

Patton, M. Q. (2014). Nitel araştırma ve değerlendirme yöntemleri [Qualitative research and evaluation methods]. (M. Bütün, \& B. Demir, Trans.). Ankara: Pegem Academi Publishing. (Original work published 2002).

Pieterse, A. L., Lee, M., Ritmeester, A., \& Collins, N. M. (2013). Towards a model of self-awareness development for counselling and psychotherapy training. Counselling Psychology Quarterly, 26(2), 190-207. https://doi.org/10.1080/09515070.2013.793451

Pompeo, A. M., \& Levitt, D. H. (2014). A path of counselor self-awareness. Counseling and Values, 59(1), 80-94. https://doi.org/10.1002/j.2161-007X.2014.00043.x

Pope, V. T., \& Kline, W. B. (1999). The personal characteristics of effective counselors: What 10 experts think. Psychological Reports, 84(3), 1339-1344.

Saban, A., \& Ersoy, A. (2016). Eğitimde nitel araştırma desenleri [Qualitative research patterns in education]. Ankara: An1 Publishing.

Schneider-Corey, M., \& Corey, G. (2002). Groups: Process and practice. Pacific Grove. CA: Brooks/Cole.

Smaby, M., Maddux, C., Richmond, A., Lepkowski, W., \& Packman, J. (2005). Academic admission requirements as predictors of counseling knowledge, personal development, and counseling skills. Counselor Education and Supervision, 45, 4357.

The Council of Higher Education [YÖK], 2018. Rehberlik ve psikolojik danışmanlık lisans programı [Guidance and psychological counseling undergraduate program.]. $\quad$ Retrieved July 25, 2020, from https://www.yok.gov.tr/Documents/Kurumsal/egitim_ogretim_dairesi/YeniOgretmen-Yetistirme-LisansProgramlari/Rehberlik_ve_Psikolojik_Danismanlik_Lisans_Programi.pdf

Topuz, C., \& Arasan, Z. (2014). Self-awareness group counseling model for prospective counselors. Procedia-Social and Behavioral Sciences, 143, 638-642.

Uhlemann, M. R., \& Jordan, D. (1981). Self-awareness and the effective counsellor: A framework for assessment. Canadian Journal of Counselling and Psychotherapy, 15(2), 70-73. 
Vallance, K. (2004). Exploring counsellor perceptions of the impact of counselling supervision on clients. British Journal of Guidance \& Counselling, 32(4), 559-574. https://doi.org/10.1080/03069880412331303330

Williams, E. N. (2003). The relationship between momentary states of therapist selfawareness and perceptions of the counseling process. Journal of Contemporary Psychotherapy, 33(3), 177-186.

Yalçın, İ. (2006). 21. yüzyılda psikolojik danışman [Psychological counselor in the $21 \mathrm{st}$ century]. Ankara University Journal of Educational Sciences, 39(1), 117-133.

Yazgan-İnanç, B., \& Yerlikaya, E. E. (2016). Kişilik kuramları [Personality theories] (12nd ed.). Ankara: Pegem Academi Publishing.

Yıldırım, A., \& Şimşek, H. (2013). Sosyal bilimlerde bilimsel araştırma yöntemleri [Scientific research methods in social sciences] (9th ed.). Ankara: Seçkin Publishing. 